Editorial

\title{
Introduction to Media History and Democracy
}

\author{
David W. Park \\ Department of Communication, Lake Forest College, Lake Forest, IL 60045, USA; E-Mail: park@lakeforest.edu
}

Submitted: 12 January 2018 | Published: 9 February 2018

\begin{abstract}
This thematic issue of Media and Communication features articles that address the workings of democracy as understood through the lens of media history. The intersection of democracy and media history brings together two impossibly expansive terms, so expansive that the articles herein cannot provide any meaningful closure to the questions that even a cursory consideration of media history and democracy would provoke. Instead of closure, what these authors develop is a demonstration of the value of media history to our understandings of democracy. Historical methods of inquiry are necessary components for any meaningful understanding of media or democracy, and the authors gathered here work from a multi-hued palette of historiographical approaches. One finds in this issue a careful attention to how issues related to media history and democracy can be investigated through consideration of intellectual history, the history of political debates, journalism history, and the history of media organizations and institutions. These articles make a strong case for the continued relevance of media history to understanding the democracy and the media.
\end{abstract}

\section{Keywords}

communication history; democracy; journalism; media; media history; public

Issue

This editorial is part of the issue "Media History and Democracy", edited by David W. Park (Lake Forest College, USA).

(C) 2018 by the author; licensee Cogitatio (Lisbon, Portugal). This article is licensed under a Creative Commons Attribution 4.0 International License (CC BY).

\section{Introduction}

It is customary for thematic issues of journals in the field of communication to be dedicated to interrogating the significance of recent events or to showcasing a novel methodology or theoretical approach. This thematic issue does neither. Neither democracy nor media history is new. To the extent that there is any recent development that this thematic issue reflects, it is the place of historical inquiry in the field of communication.

Communication history-an inclusive descriptor for all manner of scholarly combinations of history and communication, including media history-is now wellprimed to play a major role in the study of communication and the media. In the history of communication study, history itself has often played a marginal and limited role. Certainly it would be unusual to find anyone mistaking the field of communication for being primarily or unavoidably historical in tone; across much of the world the dominant schools of thought in the field of communication are tied (perhaps rather loosely) to norms of inquiry imported from the positivist social sciences. The $21^{\text {st }}$ century has witnessed an intensification of interest in communication history and an attendant binding together of those who pursue its study. In 2006, John Nerone offered an appropriately ambivalent take on communication history's recent strides. Nerone described communication history as displaying "galloping theoretical incoherence", and observed that communication history "is as interdisciplinary and eclectic as any neighborhood of scholarship anywhere" (p. 259). Though this may seem like a fatal flaw, there is glory nonetheless. As Nerone observes, "historical practice doesn't need theoretical coherence beyond what is required to be able to tell a compelling story" (p. 260).

With galloping theoretical incoherence and compelling stories alike both very much at hand, communication history has made important strides within the field of communication. This development has been most noticeable in the emergence new divisions in scholarly associations associated with communication history. The International Communication Association (ICA) and the Eu- 
ropean Communication Research and Education Association (ECREA) both adopted sections dedicated to communication history in 2007, adding their voices to the longestablished history section of the International Association for Media and Communication Research (Simonson, Peck, Craig, \& Jackson, 2013, p. 39). Communication history (including media history) turns up in a frequent-ifhaphazard manner in journals of communication, and numerous journals are dedicated entirely to media history. What we have witnessed is exactly what Nerone saw coming: a continuing interest in communication and media history that lacks disciplinary orthodoxy but provides compelling narratives. As is true of the broader history of communication study, where one searches in vain for the kind of disciplinary coherence that we sometimes pretend exists (significantly, it is historians of communication study who call our attention to the field's lack of coherence), communication history itself is fragmented. Media history has its own tendencies toward fragmentation and incoherence. Even to consider the category of "media history" leads one quickly to consult the only occasionally overlapping worlds of those who address the history of film, broadcast media, journalism, the book, the public sphere, the audience, and media technology. I should point out that this list of types of media history itself naturalizes and reproduces distinctions between types of media history as if each sub-specialty enjoys some Edenic authenticity. "Media history" itself is hard to separate from other forms of history, though the term serves us quite well if the goal (as it is here) is to pull together a relatively diverse lineup of historical manuscripts.

This issue of Media and Communication is not intended to assert a new order for the world of media history but instead to provide a demonstration of the power of media history to tell us something important. The unifying theme of democracy helps to show us that even media historians working in widely divergent domains have something important to say to each other and to everyone else. The point is not to attempt to force some cleanly drafted schematic onto the messiness of media history, or to show that each of these articles is to be combined with others to form the kind of objective history that historians have long known could no longer be constructed (Novick, 1988). The point, instead, is to demonstrate that media history can help us to think about what democracy and communication have to do with each other by showing through historical inquiry how media have played a role in constituting, sustaining, eroding, or otherwise shaping democratic processes.

\section{Articles in This Thematic Issue}

Given that this thematic issue's theme is so hopelessly broad as to foreclose any hope for finality, I suggest instead that the articles herein be read at least in part as demonstrations of how media history can be deployed to connect the infinitesimal detail to the grand narrative, and the empirical to the critical. Within media history there are numerous divergent interpretive communities, and this thematic issue gives us a taste of what some of these variants of media history resemble.

One recognizable genre of media history takes as its domain the history of media systems and institutions. Here is where the alignment between critical political economy of the media and media history is made most apparent. Inspired largely by the work of Herbert Schiller, whose Mass Communications and American Empire (1969) fitted a taut critical narrative to data drawn from US government and media systems archival documents, histories of media systems and institutions make connections between the overarching features of media systems and the countless stipples of archival data.

Kathryn Montalbano's lead article (2018) gives us a sense of how "history always constitutes the relation between a present and its past" (Berger, 1972, p. 11). Montalbano expertly charts how the National Religious Broadcasters (NRB) have operated on a grassroots level in opposition to the US Federal Communications Commission's (FCC) Fairness Doctrine, and how this history of opposition in turn informed the NRB's opposition to the FCC's Net Neutrality rules. By digging this up, Montalbano offers an innovative approach to how media history of systems and institutions can be informed by the work of grassroots activists. Beyond this, Montalbano takes the NRB's opposition to the Fairness Doctrine and Net Neutrality as a way to make plain how these potentially neutral-seeming rules (one has "neutral" in its name, after all) can highlight some particular and interested ways to conceptualize the public and how democracy ought to function.

Much as Montalbano derives historical interest from the parallax at work when regarding secular and religious understandings of free speech and the public in a communication policy context, Anne F. MacLennan (2018) finds a parallel benefit to historical understanding that can come from focusing on how national media systems impinge upon each other. MacLennan begins with the situation of Canadian broadcasters in the 1920s, when it was decidedly unclear how to arrange broadcasting, a situation made all the more complex by American broadcasting neighbors having already reached across the US/Canada border, and by the very available model of the BBC across the Atlantic. Drawing from archival sources, MacLennan argues that the emergent broadcasting system in Canada, with its blended incorporation of private and public programming, was the result in large part of the national network's relatively slow emergence, which allowed for local control to develop deep roots. MacLennan's account provides an accounting of how the contradictions at work in democratic parliamentary processes can be linked to specific media system outcomes.

This is succeeded by Bryce Peake's (2018) sweepingyet-forensic history of telegraphy in British Gibraltar, as after World War I it became transformed by wave after 
wave of reorganization and privatization. Peake's analysis benefits from a carefully explicated historiography that itself represents a break from media history as usual. Peake asserts that neoliberalism-often thought to have originated in the 1960s-is a technique that emerged from particular colonial sites of power, and his adherence to archival sources helps to underwrite the legitimacy of using the word "neoliberalism" to refer to telegraphy in the early $20^{\text {th }}$ century. Peake arrives at a "prehistory" of neoliberalism, where the system in control of telegraphy in British Gibraltar can be taken as evidence for how "political economic rationality in Europe has deeply set imperial roots" in "neoliberal transformation".

In contradistinction to the histories of media systems and institutions we find in the first three articles in this thematic issue, the fourth article, by James Anderson (2018), is intellectual history. As is often the case in intellectual history, Anderson writes about ideas, the person who developed those ideas, and the context surrounding the person and those ideas. Anderson concerns himself with one of the most familiar figures in communication study: John Dewey. Dewey's writing was not always directly relevant to media history, but Anderson focuses on how Dewey's articles for The New Republic exemplified his ideas regarding public pedagogy. Instead of simply demonstrating this rather basic and not-surprising consonance between Dewey's philosophy and his words for the public, Anderson points to the slipperiness of Dewey's attempts to shore up distinctions between individuals and society, and between public and private. Building on Randolph Bourne's criticisms of Dewey's philosophy, Anderson pushes us to imagine "the pragmatic overcoming of the private/public distinction".

A third genre of media history that receives healthy representation in this thematic issue is journalism history. Journalism history and media history have often sat at separate tables, with differently inflected observations of professional correctness, different historiographical norms, and different institutional contexts for their work. John Nerone (2011) has exhorted journalism historians to "welcome an engagement with communication as a field" (pp. 22-23), and the journalism history we find in this thematic issue represents exactly this engagement. The last three articles in this issue give us a vivid sense of how journalism history that engages with communication as a field could work to the benefit of both communication study and journalism history.

The first journalism history entry in this issue comes from Ned Randolph (2018), whose sketch of $19^{\text {th }}$ century US federal river management leads into a discussion of publicly organized river conventions, and then into a consideration of the progressive era attempts to direct public and elite opinion regarding river policy, with a strong emphasis on the role played by lobbying groups. The result of this inquiry is a decentered understanding of journalism history, where the journalism itself is made out to be only a part of a process of constituting the public in the face of a pressing issue.
Another way to decenter classic journalism history is to look beyond the hard news sections of newspapers of record, much as Barbie Zelizer (2005) suggested that journalism studies must do. In her article, Birgitte Kjos Fonn (2018) tells the story of the Norwegian business magazine Farmand, and its longstanding editor, Trygve J. B. Hoff. Fonn (2018) employs a biographical approach, focusing on Hoff himself, and how his experiences and surroundings came to shape the reporting in Farmand. In a manner that parallel's Peake's unearthing of continuities between present-day neoliberalism and colonial practice, Fonn finds in Hoff a neoliberal avant le mot, a media presence whose stubborn words in his own magazine lay plain some of the intellectual roots of what we now call neoliberalism.

The last entry of journalism history here, by Sandra Méndez-Muros (2018), considers Spanish journalism during the transition to democracy in the 1970s. Again we find a decentering move at work in this journalism history. This is not just the story of a newspaper's reporting from yesteryear. Méndez-Muros puts the reporting from the Seville newspaper (El Correo de Andalucia) in the context of social movements at the time, pairing her description of news reporting with a functional take on how this reporting came to matter to the formation of a democratic order. After situating the political backdrop of post-Franco Spain, Méndez-Muros reclaims the legacy of the neighboring movement, showing us how it has been occluded in other historical accounts, and how coverage of this movement in El Correo de Andalucia came to be linked to the goals of the demonstrators.

Taken together, the authors of these articles exemplify media history's potential. They pair an attention to evidentiary detail with cognizance of the bigger picture; they have constructed histories that connect the empirical to the critical. Put simply: these are the qualities we associate with excellent communication scholarship.

\section{Acknowledgments}

David W. Park would like to acknowledge the unstinting assistance and counsel of Rodrigo Gomes Quintas da Silva at Cogitatio Press, without whom this thematic issue could never have been created.

\section{Conflict of Interests}

The author declares no conflict of interest.

\section{References}

Anderson, J. (2018). From the Old New Republic to a Great Community: Insights and contradictions in John Dewey's public pedagogy. Media and Communication, 6(1), 34-42.

Berger, J. (1972). Ways of seeing. London: British Broadcasting Corporation.

Fonn, B. K. (2018). "Approaching an abyss": Liberalist Ide- 
ology in a Norwegian Cold War business paper. Media and Communication, 6(1), 52-61.

MacLennan, A. F. (2018). Private broadcasting and the path to radio broadcasting policy in Canada. Media and Communication, 6(1), 13-20.

Méndez-Muros, S. (2018). The media protest of neighbouring associations, promoter of citizen democratic culture during Transition in Southern Spain. Media and Communication, 6(1), 62-72.

Montalbano, K. (2018). Net neutrality, the Fairness Doctrine, and the NRB: The tension between United States religious expression and media regulation. Media and Communication, 6(1), 5-12.

Nerone, J. (2006). The future of communication history. Critical Studies in Media Communication, 23(3), 254-262.

Nerone, J. (2011). Does journalism history matter? American Journalism, 28(4), 7-27.

Novick, P. (1988). That noble dream: The 'objectivity question' and the American historical profession. Cambridge: Cambridge University Press.

Peake, B. (2018). Methodological perspectives on British commercial telegraphy and the colonial struggle over democratic connections in Gibraltar, 1914-1941. Media and Communication, 6(1), 21-33.

Randolph, N. (2018). River activism, "Levees-Only" and the Great Mississippi Flood of 1927. Media and Communication, 6(1), 43-51.

Schiller, H. (1969). Mass communications and American empire. New York, NY: A. M. Kelley.

Simonson, P., Peck, J., Craig, R. T., \& Jackson, J. P. (2013). The history of communication history. In P. Simonson, J. Peck, R. T. Craig, \& J. P. Jackson (Eds.), The handbook of communication history (pp. 13-57). New York, NY: Routledge.

Zelizer, B. (2005). The culture of journalism. In J. Curran \& M. Gurevitch (Eds.), Mass media and society (4th ed., pp. 198-214). London: Bloomsbury.

\section{About the Author}

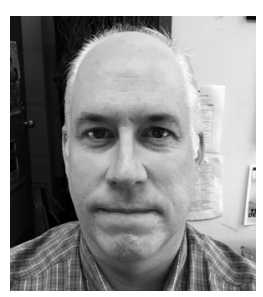

David W. Park is Professor of Communication at Lake Forest College. His scholarship usually concerns history of the study of communication and media history, particularly as these topics relate to issues in the sociology of communication. 